- FINANSE I PRAWO FINANSOWE.

- Journal of Finance and Financial Law $•$

Marzec/March 2020 • vol. 1(25): 105-121

https://doi.org/10.18778/2391-6478.1.25.07

\title{
DETERMINANTY RECESJI NA RYNKU POŻYCZEK POZABANKOWYCH W POLSCE
}

\author{
Krzysztof Waliszewski \\ Uniwersytet Ekonomiczny w Poznaniu \\ ORCID: https://orcid.org/0000-0003-4239-5875
}

\begin{abstract}
Streszczenie
Zaostrzenie regulacji w zakresie detalicznej działalności kredytowej banków (rekomendacja T KNF) doprowadziła do dynamicznego wzrostu sektora pożyczek pozabankowych w Polsce. Obok segmentu tradycyjnego (off-line) pożyczek udzielanych w domu i w punktach stacjonarnych - własnych i partnerskich, np. poprzez pośredników finansowych w związku z rozwojem nowoczesnych technologii w finansach konsumenckich (fin-tech), powstał i dynamicznie rozwinął się segment pożyczek udzielanych zdalnie (on-line, digital lending, Lendtech). W okresie dynamicznego wzrostu pozabankowego sektora pożyczkowego w życie weszło szereg regulacji o charakterze ostrożnościowym i w zakresie ochrony konsumenta-pożyczkobiorcy, a największe instytucje pożyczkowe od lutego $2016 \mathrm{r}$. zostały objęte tzw. podatkiem bankowym. Jednak statystyki rynku pożyczkowego za 2019 r. wskazują, że z miesiąca na miesiąc dynamika sprzedaży pożyczek pozabankowych spadała, aby w końcu roku osiągnąć ujemne wartości (ok. -3\%), oznaczające w praktyce stan recesji tego rynku. Celem artykułu jest identyfikacja determinant zaobserwowanej w 2019 r. recesji rynku pożyczek pozabankowych. W artykule wykorzystano literaturę przedmiotu, na którą składają się akty prawne, artykuły naukowe, raporty i dane statystyczne.
\end{abstract}

Słowa kluczowe: pożyczki pozabankowe, kredyt konsumencki, rynek consumer finance, przepisy antylichwiarskie.

JEL Class: G28, L40, D10, D18. 


\section{WPROWADZENIE}

Instytucje pożyczkowe w rozwiniętych gospodarkach rynkowych, w tym również w Polsce, są częścią rynku finansowania konsumpcji (consumer finance) obejmującego produkty kredytowe o stosunkowo niskich kwotach i na krótkie okresy. Biorąc pod uwagę kryterium podmiotowe, na rynku tym poza bankami uniwersalnymi (komercyjnymi) i spółdzielczymi działają również spółdzielcze kasy oszczędnościowo-kredytowe, niebankowe instytucje pożyczkowe, pośrednicy i doradcy kredytowi, a także banki specjalizujące się w udzielaniu kredytów konsumenckich [Ancyparowicz i Rutkowska 2014; Solarz 2007]. Jest to rynek bardzo atrakcyjny z biznesowego punktu widzenia, ponieważ pozwala realizować stosunkowo wysokie marże kredytowe, ale jednocześnie narażony jest na najwyższe ryzyko braku spłat. Na rynek ten wpływa wiele czynników o charakterze makroekonomicznym, społecznym i demograficznym [Gostomsk i Lepczyński 2009; Barczuk 2011]. W zakresie produktowym rynek ten obejmuje pożyczki pozabankowe, bankowe pożyczki gotówkowe, pożyczki od SKOK-ów, kredyty ratalne, karty kredytowe, w tym karty private label, limity w rachunkach oszczędnościowo-rozliczeniowych [Waliszewski 2010]. W ostatnich kilku latach wzrosło znaczenie instytucji pożyczkowych na rynku consumer finance, co było z jednej strony związane $\mathrm{z}$ coraz bardziej restrykcyjnymi regulacjami w zakresie detalicznej działalności kredytowej banków (rekomendacje KNF), a z drugiej strony z rozwojem nowoczesnych technologii na rynku pożyczkowym, którą preferują osoby wykształcone, z dużych miast, ceniące sobie elastyczność i wygodę. Udział sektora pożyczkowego w rynku consumer finance wg wartości udzielonych pożyczek w $2018 \mathrm{r}$. był nieznaczny i wynosi ok. 7\%, jednak biorąc pod uwagę udział wg liczby zawartych umów był znaczny, bo wynosił ponad $20 \%$. W poszczególnych latach obserwowano dodatnią dynamikę wzrostu rynku pożyczkowego aż do 2019 r., gdy wartość udzielonych pożyczek rok do roku była ujemna na poziomie $4,2 \%$. W związku ze zmianą trendu dynamiki wartości sprzedaży pożyczek pozabankowych z dodatniej na ujemną, wyjaśnienie przyczyn tej zmiany jest celem niniejszego tekstu. Autor chciałby udowodnić hipotezę, że recesja na rynku pożyczkowych w 2019 r. ma swoje podłoże w czynnikach ekonomicznych i regulacyjnych, a także wynika z problemów w finansowaniu działalności przez instytucje pożyczkowe, które mają źródło w kryzysie na rynku obligacji korporacyjnych związanym z problemami spółki GetBack S.A. 


\section{RYNEK POŻYCZEK POZABANKOWYCH W POLSCE W LATACH 2007-2019}

Pierwszą w Polsce instytucją pożyczkową prowadzącą działalność na terenie całego kraju i w związku z tym rozpoznawalną w skali ogólnopolskiej jest spółka Provident, powstała w 1997 r., będąca częścią międzynarodowej grupy International Personal Finance. Jest spółką publiczną notowaną - w ramach tzw. notowania równoległego (dual-listing) - na Giełdzie Papierów Wartościowych w Warszawie (od 27 marca 2013 r.) oraz London Stock Exchange (od 2007 r.). Przedsiębiorstwo jest liderem na polskim rynku pożyczek pozabankowych (pay-day loan). Oferuje pożyczki z możliwością spłaty w dwóch opcjach: obsługa w domu klienta (home credit) lub przelew z konta bankowego. W 2013 roku spółka wprowadziła również nowy produkt - pożyczki dla mikroprzedsiębiorców. W 2014 roku oferta poszerzyła się o pożyczkę konsolidacyjną, a także pożyczkę ze spłatą w miesięcznych ratach (w pozostałych przypadkach standardem jest rata cotygodniowa). Provident rozpoczął również współpracę z AXA, dzięki czemu zaoferował jako dodatek do pożyczki pakiet medyczny za darmo. W styczniu 2016 r. firma zdywersyfikowała swoje usługi w Polsce, wprowadzając do oferty rozwiązania finansowe przez Internet poprzez markę Happi pożyczki. Do 2015 r., kiedy w życie weszły przepisy antylichwiarskie limitujące odsetki maksymalne do 4-krotności stopy lombardowej NBP, spółka była znana z bardzo wysokich kosztów odsetkowych swoich pożyczek, sięgających w skali roku kilku tysięcy procent, co można określić jako lichwa (fringe banking). W kolejnych latach XXI w. do Providenta zaczęły dołączać inne podmioty - Profi Credit, Everest Finanse (Bocian Pożyczki), Pożyczki-Chwilówki, Kreditech, Vivus, Wonga, co doprowadziło do polaryzacji podmiotów wokół 3 segmentów - rynku tradycyjnego działającego w kanałach stacjonarnych (off-line) - w domu (segment domowy), w oddziałach własnych i placówkach partnerskich, np. u pośredników finansowych (segment oddziałowy), a także nowego i dynamicznie rosnącego kanału zdalnego (on-line) obejmującego telefon i Internet. $\mathrm{Z}$ czasem znaczenie tego drugiego kanału stało się tak duże, jak kanału tradycyjnego - wg danych za 2017 r. udział obu kanałów w rynku wynosił po ok. 50\%. Segmentację rynku pożyczkowego w Polsce przedstawia rysunek 1 .

Jak wskazuje tabela 1 segmenty tradycyjne (off-line) obsługi domowej, oddziałowy i on-line różnią się sposobem pozyskania klienta, procedurą i czasem podjęcia decyzji pożyczkowej, sposobem zawarcia umowy i transferu środków finansowych, a także sposobem spłaty rat kapitałowo-odsetkowych. Wskazane różnice wpływają również na stronę finansową modeli biznesowych realizowanych w poszczególnych segmentach rynku, tzn. na poziom przychodów, kosztów, rentowność, średnią wartość pożyczki, szkodowość. 


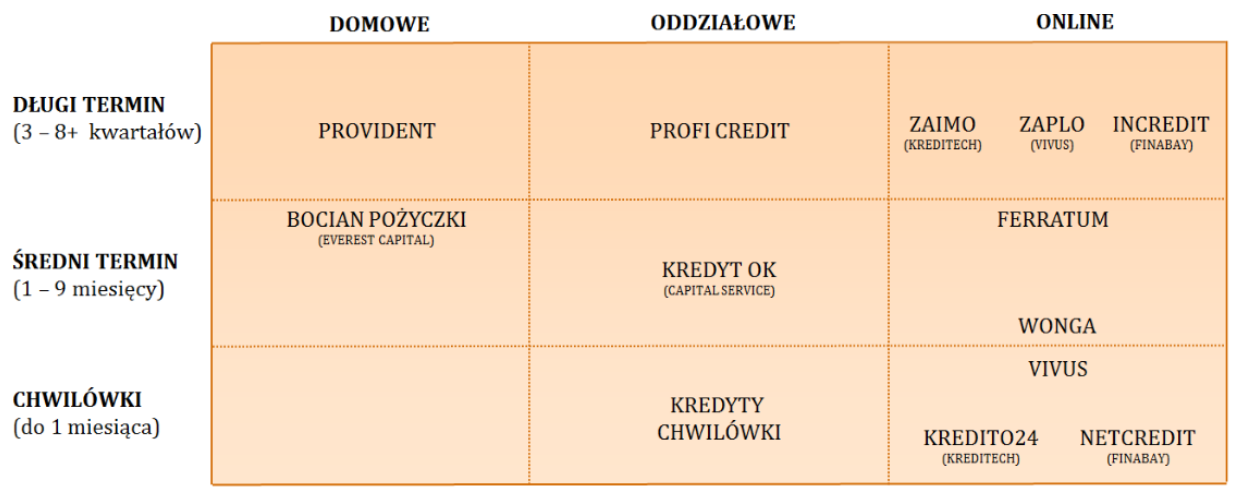

Rysunek 1. Segmentacja rynku pożyczkowego w Polsce

Źródło: Rynek firm pożyczkowych ..., dostęp 31.12.2019.

Tabela 1. Porównanie segmentów rynku pożyczkowego w Polsce

\begin{tabular}{|c|c|c|}
\hline \multicolumn{2}{|c|}{ Segmenty off-line } & \multirow{2}{*}{ Segment on-line } \\
\hline Segment domowy & Segment oddziałowy & \\
\hline Pozyskanie klienta & Pozyskanie klienta & Pozyskanie klienta \\
\hline Sieć doradców klienta & Ogólnokrajowa sieć oddziałów & Intensywne kampanie ATL/BTL \\
\hline Infolinia / formularz na stronie & Infolinia / formularz & Dopracowany serwis internetowy \\
\hline Instensywne kampanie reklamowe & Kampanie ATL & Programy partnerskie \\
\hline Decyzja kredytowa & Decyzja kredytowa & Decyzja kredytowa \\
\hline Subiektywna ocena agenta & Weryfikacja w oddziale & Kilka - kilkadziesiąt minut \\
\hline Weryfikacja danych i BIK & Decyzja podczas wizyty, duże & W oparciu o rejestry dłużników \\
\hline Czas: $1-2$ dni & pożyczki w ciągu 24 godzin & Najostrzejsze kryteria \\
\hline Zawarcie umowy & Zawarcie umowy & Zawarcie umowy \\
\hline i transfer środków & i transfer środków & i transfer środków \\
\hline \multirow[t]{2}{*}{ Dostarczane przez agenta } & Umowa zawierana w oddziale & „Podpisanie” umowy przelewem \\
\hline & Przelew na konto klienta & Pożyczka przekazana na konto \\
\hline Splata długu & Splata długu & Splata długu \\
\hline Obsługa domowa (cotygodniowe & System ratalny & Wyłącznie przelewem \\
\hline wizyty) lub przelew & Przelew lub gotówka & Zazwyczaj jednorazowa \\
\hline
\end{tabular}

Źródło: opracowanie własne na podstawie Rynek firm pożyczkowych ..., dostęp 31.12.2019. 
Biorąc pod uwagę produkt bankowy - pożyczkę gotówkową i produkt pozabankowy - pożyczkę pozabankową ze względu na średnią wartość (kredyty konsumpcyjne średnia wartość ok. $11893 \mathrm{zt}^{1}$, pożyczki pozabankowe średnia wartość $2485 \mathrm{zł}^{2}$ ) i termin spłaty, są to produkty w dużej mierze komplementarne a nie substytucyjne, co potwierdza, iż rynek pożyczkowy raczej dopełnia ofertę bankową niż z nią konkuruje. Może zastanawiać, kto korzysta z pożyczek pozabankowych - w części są to osoby wykluczone kredytowo z sektora bankowego, ale w części są to osoby ubankowione, tzn. posiadające rachunek bankowy i kredyt bankowy, z wyższym wykształceniem i z dużych miast, co wskazuje na przenikanie się sektora bankowego i pozabankowego [Waliszewski 2017]. Również powszechnie powielana informacja, że instytucje pożyczkowe nie badają zdolności i wiarygodności klientów przed udzieleniem finansowania jest nieprawdziwa, ponieważ zgodnie z przepisami prawa, mają obowiązek badać ryzyko kredytowe przed udzieleniem pożyczki, w tym badać klienta w bazach BIK lub BIG-ów, a poziom odrzucanych wniosków jest wysoki i wynosi ok. 70\%. Rozwój sektora pożyczkowego w Polsce był zdeterminowany czynnikami ekonomicznymi, regulacyjnymi, technologicznymi i społecznymi, a także był wspierany bardzo aktywną działalnością marketingową instytucji pożyczkowych, plasującą ten sektor wśród największych reklamodawców w branży finansowej, budującą i utrwalającą świadomość poszczególnych marek.

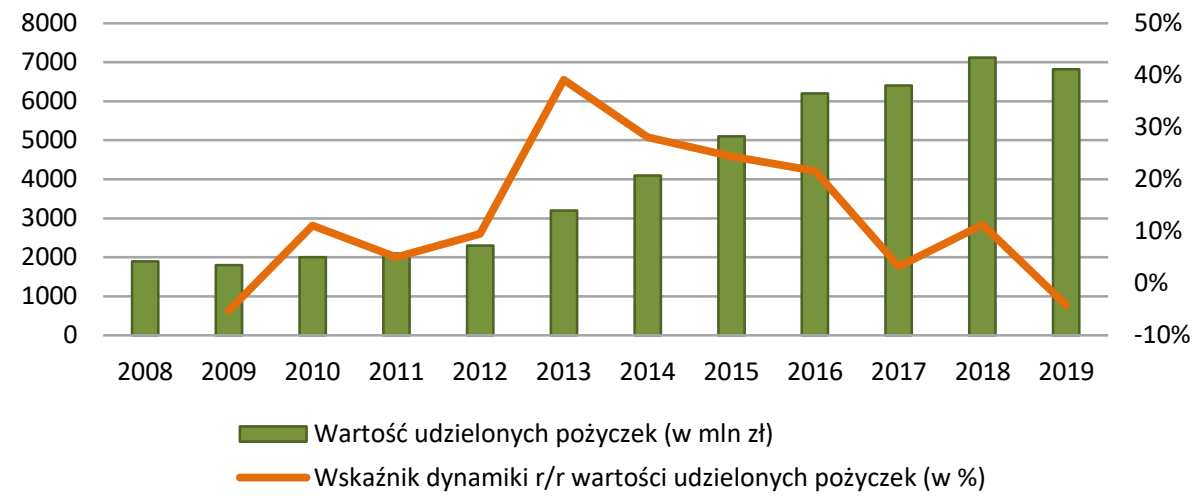

Wykres 1. Charakterystyka rynku pożyczkowego w Polsce - roczna sprzedaż pożyczek (w mln zł) i dynamika sprzedaży $\mathrm{r} / \mathrm{r}(\mathrm{w} \%)$

Źródło: opracowanie własne na podstawie danych Polskiego Związku Instytucji Pożyczkowych, Związku Przedsiębiorstw Finansowych, Biura Informacji Kredytowej.

\footnotetext{
${ }^{1}$ Według danych BIK za 2019 r.

${ }^{2}$ Według danych BIK za 2019 r.
} 
Dynamiczny rozwój rynku pożyczkowego w Polsce był możliwy, ponieważ od początku 2011 r. Komisja Nadzoru Finansowego wprowadziła rekomendację T, dotyczącą zarządzania ryzykiem ekspozycji detalicznych w bankach [Rekomendacja $T$ dotyczaca dobrych praktyk...]. Implementacja tej rekomendacji m.in. poprzez wprowadzenie maksymalnego wskaźnika miesięcznego zadłużenia do miesięcznych dochodów DtI (debt to income $)^{3}$ na poziomie 50 i $65 \%$ dla osób osiągających dochody powyżej przeciętnego wynagrodzenia oznaczała w praktyce wykluczenie kredytowe (credit exclusion) części klientów dotychczas obsługiwanych przez banki poza sektor bankowy. Dopiero nowelizacja rekomendacji T z lutego $2013 \mathrm{r}$., obowiązująca od końca lipca 2013 r., zniosła te wartości, pozostawiając bankom ich określenie w ramach wewnętrznych polityk kredytowych [Waliszewski 2016]. Jak wskazują dane obrazujące wielkość rynku pożyczkowego w Polsce, w latach 2008-2019 (wykres 1) rynek ten wzrósł z ok. 2 mld zł udzielanych pożyczek rocznie do 7,4 mld zł w 2018 r. i 6,82 mld zł w 2019 r. Jednocześnie w 2014 r. nastąpiło podwojenie wartości tego rynku w stosunku do roku 2008 - 4,1 mld zł udzielonych pożyczek, a w 2017 r. potrojenie do wartości 6,4 mld zł, przy czym tak dynamiczny wzrost był możliwy dzięki powstaniu i rozwojowi segmentu pożyczek internetowych, którego wartość w latach 2013-2017 uległa potrojeniu z 1,1 mld zł do 3,3 mld zł. Od 2013 r., gdy dynamika wzrostu rynku była najwyższa i wyniosła $39 \%$, obserwuje się coraz wolniejszy wzrost akcji pożyczkowej - w 2017 r. wskaźnik dynamiki rocznej sprzedaży pożyczek rok do roku wynosił $13 \%$, jednak w 2019 r. był ujemny na poziomie 4,2\%, co oznacza regres i recesję rynku pożyczkowego w Polsce.

\section{REGULACJE OSTROŻNOŚCIOWE I KONSUMENCKIE DOTYCZĄCE POZABANKOWEGO RYNKU POŻYCZKOWEGO W POLSCE}

Początkowo regulacje pozabankowego sektora pożyczkowego nie nadążały za jego dynamicznym rozwojem i sektor pożyczek pozabankowych był traktowany jako element nieregulowanego, równoległego sektora bankowego (shadow banking system) i do sektora parabankowego (fringe banking). Przez to nie można było skutecznie zapobiegać nadużyciom, do jakich dopuszczali się pożyczkodawcy wobec konsumentów, np. pobieranie nadmiernych pozaodsetkowych kosztów pożyczek, w tym opłat za administrację, za rolowanie pożyczek, za odbiór rat w domu [Czechowska 2015; Opolski i in. 2015]. Brak publicznego rejestru instytucji pożyczkowych prowadził do braku kontroli ze strony państwa nad tym

${ }^{3}$ Jest to wskaźnik określający relację wydatków związanych z obsługą zobowiązań kredytowych i zobowiązań finansowych innych niż zobowiązania kredytowe do dochodów klientów detalicznych. 
segmentem rynku usług finansowych, a także oznaczał brak przestrzegania żadnych wymogów formalnych przez przedsiębiorców udzielających pozabankowych pożyczek konsumenckich. W miarę jak nasilały się negatywne zjawiska, pojawiła się koncepcja uregulowania rynku pożyczkowego [Domańska-Szaruga 2015] w celu zapewnienia bezpieczeństwa finansowego konsumentów jako nieprofesjonalnych uczestników obrotu gospodarczego [Domańska-Szaruga 2016]. Należy dodać, że niebankowe instytucje pożyczkowe w relacjach z konsumentami były związane przepisami ustawy o kredycie konsumenckim z dnia 12 maja $2011 \mathrm{r}$. [Dz.U. 2019, poz. 1083 z pózn. zm.] i jej wcześniejszą wersją z dnia 20 lipca 2001 r. [Dz.U. 2001, nr 100, poz. 1081 z pózn. zm.].

Wszystkie te argumenty przesądziły o zaostrzeniu regulacji tego rynku w 2015 r. Ustawą z dnia 5 sierpnia 2015 r. o zmianie ustawy o nadzorze nad rynkiem finansowym i niektórych innych ustaw [Dz.U. 2015, poz. 1357] wprowadzono do ustawy z dnia 12 maja 2011 r. o kredycie konsumenckim przepisy dotyczące wprost instytucji pożyczkowych, które zaczęły obowiązywać od 11 marca 2016 r. Przepisy te dotyczyły następujących obszarów działalności instytucji pożyczkowych:

1. Wprowadzenie definicji legalnej instytucji pożyczkowej, zgodnie z którą instytucja pożyczkowa to kredytodawca kredytu konsumenckiego inny niż:

a) bank krajowy, bank zagraniczny, oddział banku zagranicznego, instytucja kredytowa lub oddział instytucji kredytowej w rozumieniu ustawy z dnia 29 sierpnia 1997 r. - Prawo bankowe [Dz.U. 2019, poz. 2357 ze zm.],

b) spółdzielcza kasa oszczędnościowo-kredytowa oraz Krajowa Spółdzielcza Kasa Oszczędnościowo-Kredytowa w rozumieniu [Dz.U. 2019, poz. 2412 ze zm.],

c) podmiot, którego działalność polega na udzielaniu kredytów konsumenckich w postaci odroczenia zapłaty ceny lub wynagrodzenia na zakup oferowanych przez niego towarów i usług.

2. Ograniczenie możliwości spłaty zaciągniętej pożyczki nową pożyczką tzw. rolowanie pożyczki poprzez wyliczanie pozaodsetkowych kosztów łącznie od pożyczki pierwotnie zaciągniętej i nowej pożyczki zaciąganej na jej spłatę. W praktyce mechanizm rolowania został zastąpiony przez rynek mechanizmem refinansowania. Takie refinansowanie jest możliwe, jeśli klient zaciągnął pożyczkę w jednej firmie pożyczkowej, ale pożyczkę refinansową weźmie w innej. Wówczas nie obowiązują limity kosztów pożyczki łącznie, ale oddzielnie dla każdego zobowiązania. Tymczasem oba podmioty udzielające pożyczki mogą być zależne od siebie.

3. Wprowadzenie maksymalnych pozaodsetkowych kosztów kredytu konsumenckiego (MPKK).

4. Wprowadzenie maksymalnych opłat windykacyjnych za opóźnienie. 
5. Wprowadzenie określonej formy prawnej dla instytucji pożyczkowej jako spółki z o. o. lub spółki akcyjnej.

6. Wprowadzenie wymogów wobec członków zarządu, rady nadzorczej, prokurentów instytucji pożyczkowej, ponieważ może być nim wyłącznie osoba, która nie była prawomocnie skazana za przestępstwo przeciwko wiarygodności dokumentów, mieniu, obrotowi gospodarczemu, obrotowi pieniędzmi i papierami wartościowymi lub przestępstwo skarbowe.

7. Wprowadzenie minimalnego wymogu kapitałowego w wysokości 200 tys. zł i formy kapitału zakładowego instytucji pożyczkowej w postaci wkładu pieniężnego. Środki na pokrycie tego kapitału nie mogą pochodzić z kredytu, pożyczki, emisji obligacji lub ze źródeł nieudokumentowanych.

8. Wprowadzenie prawnej możliwości udostępniania przez instytucje pożyczkowe informacji Biuru Informacji Kredytowej w zakresie niezbędnym do oceny zdolności kredytowej konsumenta i analizy ryzyka kredytowego przy zachowaniu tajemnicy bankowej co do informacji pozyskanych z baz BIK przez zarząd i pracowników instytucji pożyczkowej.

9. Wprowadzenie penalizacji za nie stosowanie nowych regulacji przez podmioty udzielające konsumenckich pożyczek pozabankowych w formie grzywny do 500000 złotych i kary pozbawienia wolności do lat 2, a także za nie zachowanie tajemnicy bankowej co do informacji kredytowej w formie grzywny do 1000000 złotych i karze pozbawienia wolności do lat 3 .

10.KNF uzyskała prawo do prowadzenia postępowania wyjaśniającego, w toku którego objęte nim podmioty są zobowiązane do przedłożenia dokumentów na żądanie prowadzących postępowanie pracowników.

Uzupełnieniem przepisów z 2015 r. były te wprowadzone przy okazji implementacji do polskiego porządku prawnego dyrektywy hipotecznej (Dyrektywa MCD, Mortgage Credit Directive). W dniu 22 lipca 2017 r. weszła w życie ustawa z 23 marca 2017 r. o kredycie hipotecznym oraz o nadzorze nad pośrednikami kredytu hipotecznego i agentami [Dz.U. 2017, poz. 819], nowelizująca ustawę z dnia 12 maja 2011 roku o kredycie konsumenckim, m.in. poprzez dodanie artykułów, które dotyczą konieczności uzyskania wpisu instytucji pożyczkowej do rejestru prowadzonego przez KNF [www1]. Według stanu na koniec 2019 r., w rejestrze instytucji pożyczkowych wpisanych było 499 podmiotów. Funkcjonowanie rejestru nie należy utożsamiać z objęciem przez KNF instytucji pożyczkowym nadzorem finansowym podobnym do nadzoru bankowego, a uzyskanie wpisu do rejestru jest uzależnione od spełnienia szeregu warunków formalnych [Bernat 2018].

Wprowadzenie przepisów antylichwiarskich w odniesieniu do kredytu konsumenckiego, w tym do pożyczki pozabankowej istotnie wpłynęło na model biznesowy instytucji pożyczkowych. Wprowadzony wzór na MPKK ma następującą postać: 


$$
M P K K \leq(K \times 25 \%)+(K \times n / R \times 30 \%) \leq 100 \% \times K \text { w całym okresie }
$$

gdzie:

$K$ - kwota kapitału,

$n$ - okres kredytowania,

$R$ - liczba dni w roku.

W okresie kredytowania do 30 miesięcy maksymalne koszty pozaodsetkowe kredytu konsumenckiego rosną w sposób liniowy, a od 30 miesiąca pozostają stałe na poziomie $100 \%$.

W statystykach rynku pożyczkowego widoczny jest wpływ obowiązujących od marca 2016 r. regulacji, który wyraża się [Kurzępa-Depo i Gemzik-Salwach 2018a; Kurzępa-Dep i Gemzik-Salwach 2018b; Pindel i Martysz 2019]:

- zwiększaniem średniej kwoty pożyczki;

- wydłużaniem średniego okresu spłaty pożyczki;

- zwiększeniem udziału dystrybucji poprzez kanały zdalne (on-line), w których obsługa klienta jest tańsza niż w przypadku kanałów tradycyjnych (off-line);

- zmniejszeniem liczby podmiotów świadczących usługi pożyczkowe na skutek wprowadzenia wymogów co do formy prawnej, wysokości i formy kapitału własnego oraz ograniczeń maksymalnych pozaodsetkowych kosztów pożyczki konsumenckiej;

- pogorszeniem sytuacji finansowej i rentowności instytucji pożyczkowych skutkującym osiąganiem strat i wycofaniem się z rynku pożyczkowego szczególnie mniejszych firm;

- wzrostem odsetka wniosków odrzucanych do ok. 66\% w 2017 r. i zmniejszeniem poziomu akceptacji (approval rate) do ok. 34\% (dane KPF za 2017 r.). Przykładowo w 2010 r. poziom odrzucanych wniosków wynosił $34 \%$, a poziom akceptacji $66 \%$.

Interesujących danych o sektorze instytucji pożyczkowych oraz klientach korzystających z pozabankowej pożyczki konsumenckiej dostarczają statystyki tego rynku w odniesieniu do segmentu tradycyjnego (placówki stacjonarne, obsługa domowa), określanego jako off-line oraz segmentu kanałów zdalnych, określanych jako on-line. Obserwuje się wzajemne przenikanie działalności podmiotów należących wcześniej do jednego z wybranych segmentów, np.: Provident Polska działający w kanale stacjonarnym z obsługą domową utworzył markę Hapi Pożyczki oferującą pożyczki przez Internet. 


\section{3. ŹRÓDŁA FINANSOWANIA DZIAŁALNOŚCI PRZEZ INSTYTUCJE POŻYCZKOWE W POLSCE}

Instytucje pożyczkowe nie przyjmują depozytów od klientów, w związku z czym nazywane są instytucjami pożyczkowymi udzielającymi pożyczek ze środków własnych. W praktyce jednak w niewielkim stopniu finansują swoją działalność $\mathrm{z}$ kapitału własnego w pełnym tego słowa znaczeniu, a w większości korzystają z kapitałów obcych. Mogą to być kredyty bankowe, pożyczki pozabankowe od właścicieli, a także emisja obligacji korporacyjnych, które mogą być notowane na rynku papierów dłużnych GPW - Catalyst. Określone źródło finansowania, poza dostępnością, różni się kosztem finansowania, co ostatecznie wpływa na rentowność biznesu pożyczkowego. Dostępność poszczególnych źródeł finansowania zależała również od tego, czy dana instytucja pożyczkowa jest częścią międzynarodowej grupy finansowej, czy prowadzi tylko działalność na terenie Polski. Natomiast dostępność finansowania instytucji pożyczkowych w formie obligacji była uzależniona od zainteresowania inwestorów tego typu papierami korporacyjnymi, a ta z kolei zależała od oprocentowania obligacji, perspektyw rozwoju sektora pożyczkowego i samego emitenta, a także skali nie wywiązywania się z zobowiązań obligacyjnych przez instytucje pożyczkowe (w 2017 r. spółka Eurocent nie wykupiła obligacji o wartości ponad $1 \mathrm{mln}$ zł, a w 2018 r. o wartości 2,3 mln zł).

Zobowiązania wszystkich instytucji pożyczkowych w 2017 r. wynosiły 3,9 mld zł. Za 79\% wartości zobowiązań odpowiada 10 spółek. Zobowiązania 10 największych instytucji pożyczkowych zwiększyły się o 4,5\%. Warto przy tym zauważyć, że czołowe instytucje pożyczkowe w tym samym okresie odnotowały spadek zysku netto. W 2016 r. przeciętna rentowność obligacji brutto wahała się od 5 do 7\%, by w kolejnym roku zwiększyć się od 6 do 9\%. Wpływ na to miała niepewność regulacyjna, a także kilka upadłości firm pożyczkowych, które nie sprostały nowym wymogom prawnym i nie potrafiły dostosować swojej oferty do nowych warunków ekonomicznych. Polityka kredytowa jest zacieśniana. Instytucjom pożyczkowym coraz bardziej zaczyna zależeć na trwałej relacji ze sprawdzonym klientem, co oznacza pracę na znanym portfelu [Sektor pożyczek pozabankowych, 2019].

Ciekawych informacji odnośnie struktury finansowania instytucji pożyczkowych w Polsce dostarcza przeprowadzone przez BIK badanie sprawozdań finansowych 39 wybranych instytucji pożyczkowych za 2017 r. Na sumę bilansową wynoszącą 5,6 mld zł na kapitały własne przypadało 2,2 mld zł, co stanowiło $39 \%$ sumy pasywów, a na kapitały obce, czyli zobowiązania i rezerwy przypadało 3,4 mld zł stanowiące $61 \%$ pasywów. Z tej kwoty na poszczególne źródła kapitału obcego przypadało [Cholewa 2018]: 
1. kredyty i pożyczki $1,8 \mathrm{mld}$ zł, co stanowiło $32 \%$ pasywów,

2. emisja papierów wartościowych $0,2 \mathrm{mld} z$ z, co stanowiło blisko $4 \%$ pasywów,

3. zobowiązania wobec jednostek powiązanych $0,8 \mathrm{mld} \mathrm{zl}$, co stanowiło ponad $14 \%$ pasywów,

4. pozostałe zobowiązania i rezerwy $0,6 \mathrm{mld}$ zł, co stanowiło blisko $11 \%$ pasywów.

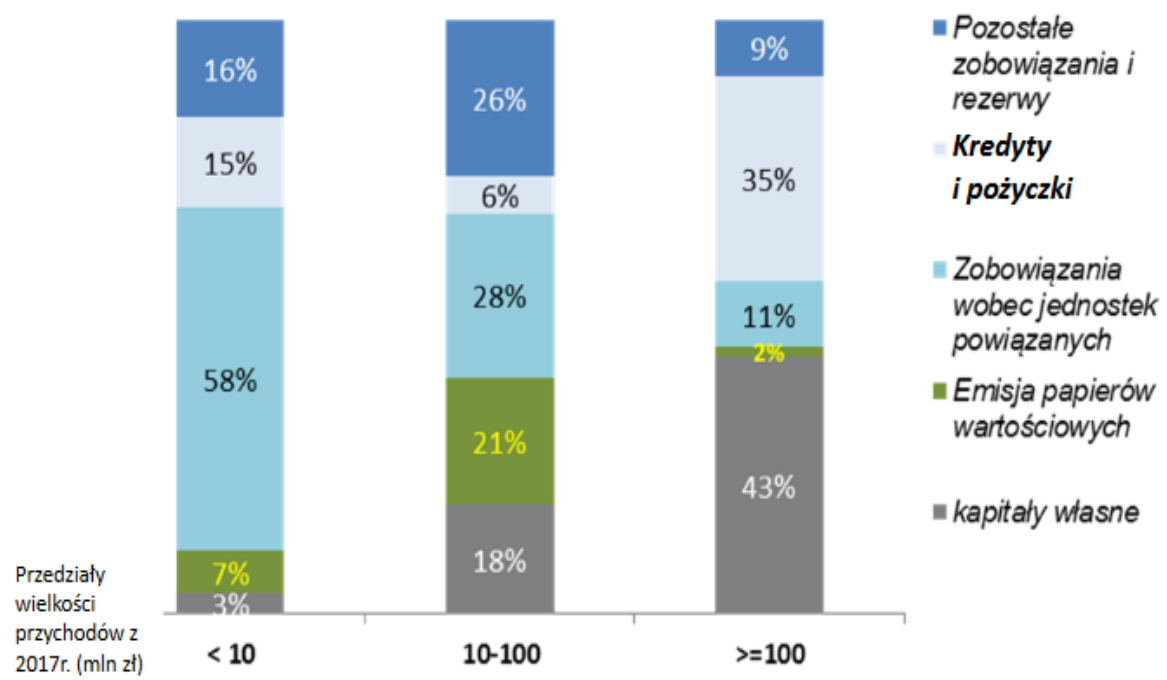

Wykres 2. Źródła finansowania firm pożyczkowych według przedziałów wielkości przychodów

Źródło: Cholewa, 2018.

Źródła finansowania instytucji pożyczkowych są również zróżnicowane w zależności od wielkości instytucji mierzonej sumą przychodów ze sprzedaży, co przedstawiono na wykresie 2 . Spółki małe, z przychodami do $10 \mathrm{mln}$ zł, finansują się głównie z zobowiązań od jednostek powiązanych (58\%), następnie z pozostałych zobowiązań i rezerw (16\%), kredytów i pożyczek (15\%), emisji obligacji korporacyjnych (7\%) i kapitałów własnych (3\%). Spółki średnie, o przychodach między 10 a $100 \mathrm{mln}$ zł, mają najbardziej zróżnicowaną, ale jednocześnie stabilną strukturę finansowania, ponieważ finansują się głównie z zobowiązań wobec jednostek powiązanych $(28 \%)$, pozostałych zobowiązań i rezerw $(26 \%)$, emisji papierów wartościowych (21\%), kapitałów własnych (18\%) i kredytów i pożyczek $(6 \%)$. Największe spółki pożyczkowe, o przychodach ze sprzedaży 
powyżej 100 mln zł, opierają swoje finansowanie głównie o środki własne (43\%), następnie o kredyty i pożyczki (35\%), zobowiązania wobec jednostek powiązanych (11\%), pozostałe zobowiązania i rezerwy $(9 \%)$ oraz emisję papierów wartościowych (2\%). Największy udział kredytów bankowych w finansowania dużych instytucji pożyczkowych wynikał z wiarygodności takich instytucji dla banków, a także z możliwości ustanowienia określonych prawnych zabezpieczeń spłaty kredytów.

\section{PRZYCZYNY RECESJI NA RYNKU POZABANKOWYCH POŻYCZEK PIENIĘŻNYCH}

Przyczyn obserwowanego w 2019 r. stanu recesji na rynku pożyczek pozabankowych można upatrywać w wielu obszarach, ale najważniejsze z nich mają podłoże ekonomiczne i regulacyjne.

W zakresie przesłanek ekonomicznych w 2019 r. następował wzrost wynagrodzeń w gospodarce, co oznaczało spadek popytu na najniższe produkty w związku z bogaceniem się społeczeństwa. Ponadto od dnia 1 lipca 2019 r. zmianie uległ sztandarowy program rządu 500+, w wyniku której programem zostało objęte również pierwsze dziecko, a zwiększenie transferów socjalnych do polskich rodzin zmniejszyło popyt na pożyczki. Nie bez znaczenia dla działalności instytucji pożyczkowych miała afera na rynku obligacji korporacyjnych spowodowana problemami spółki windykacyjnej GetBack S.A. Instytucje pożyczkowe, które dotąd finansowały się w części z emisji papierów wartościowych zaczęły mieć problemy z finansowaniem działalności. Spółki pożyczkowe poza liderami branży mają ograniczoną zdolność do pozyskiwania finansowania z tytułu kredytów bankowych oraz obligacji w kanale inwestorów instytucjonalnych. Wiele z nich do kontynuacji rozwoju potrzebuje środków z emisji obligacji plasowanych $\mathrm{u}$ inwestorów indywidualnych. A sytuacja z GetBackiem wpłynęła na zmniejszenie zainteresowania inwestorów detalicznych obligacjami - obserwowane jest wstrzymanie decyzji o inwestycjach, większa selektywność (Rudke 2018). W ramach czynników ekonomicznym można wskazać również ekspansję banków w segmencie klienta near prime ${ }^{4}$, a na tych skupiają się firmy pożyczkowe działające on-line.

Druga grupa czynników jest związana z regulacjami prawnymi rynku pożyczkowego. Wprowadzone w 2016 r. ograniczenia kosztów pożyczek zmieniły model instytucji pożyczkowych, jednak w związku z rosnącymi kosztami pozyskiwania finansowania przez instytucje pożyczkowe część produktów stała się nierentowna, a instytucje pożyczkowe je oferujące musiały zaprzestać działalności. Można mówić o konsolidacji branży, która w efekcie prowadzi do zmniejdobra.

${ }^{4}$ Klienci prawie pierwszorzędni posiadają historię kredytową, ale nie jest ona szczególnie 
szenia sprzedaży pożyczek ogółem. Drugą przyczyną w tym obszarze jest niepewność regulacyjna związana z ogłoszonym w lutym 2019 r. nowym projektem ustawy antylichwiarskiej zaproponowanym przez Ministerstwo Sprawiedliwości [Projekt ustawy o zmianie niektórych ustaw $w$ celu przeciwdziałania lichwie $z$ dnia 18 lutego 2019 r.], a oznaczającym dalsze zmniejszenie maksymalnych pozaodsetkowych kosztów kredytu konsumenckiego (MPKK) oraz wprowadzenie nadzoru Komisji Nadzoru Finansowego nad instytucjami pożyczkowymi. W projekcie tym zapisano, że wzór na MPKK będzie miał postać:

$$
M P K K \leq(K \times 20 \%)+(K \times n / R \times 25 \%) \leq 75 \% \times K \text { w całym okresie }
$$

gdzie:

$K$ - kwota kapitału,

$n$ - okres kredytowania,

$R$ - liczba dni w roku.

Jednak 18 czerwca 2019 r. rząd przyjął projekt ustawy antylichwiarskiej w zmodyfikowanje formie, zmieniając również formułę obliczania MPKK na następującą:

$$
M P K K \leq(K \times 10 \%)+(K \times n / R \times 10 \%) \leq 75 \% \times K \text { w całym okresie }
$$

gdzie:

$K$ - kwota kapitału,

$n$ - okres kredytowania,

$R$ - liczba dni w roku.

Jest to precedens, żeby po fazie konsultacji międzyresortowych i społecznych zmieniać tak krytyczny element ustawy, zwłaszcza że dyskusja publiczna o obniżeniu limitu z obecnych 25 i 30\% do zaproponowanych pierwotnie przez Ministerstwo Sprawiedliwości poziomów (20 i 25\%) trwała rok i wsparta była licznymi analizami. Przyjęcie ustawy w tym nowym kształcie oznaczałoby praktycznie likwidację branży pożyczkowej w Polsce, ze względu na nieopłacalność biznesową udzielania pożyczek konsumentom. Następnie polski rząd złożył do Komisji Europejskiej projekt ustawy o zmianie niektórych ustaw w celu przeciwdziałania lichwie notyfikację do Komisji Europejskiej, która do 30 września 2019 r. wydała swoją opinię nie zgłaszając żadnych uwag. Jak napisano w złożonym wniosku, projekt ustawy będzie oddziaływał na usługi pożyczek świadczonych drogą elektroniczną, tj. projekt może w swoich skutkach spowodować wzrost zainteresowania i popularności pożyczek udzielanych $\mathrm{w}$ relacjach pomiędzy zainteresowanymi osobami fizycznymi z pominięciem pośrednictwa insty- 
tucji finansowej, w tym za pomocą specjalnych portali internetowych. Jednak koniec kadencji Sejmu i wybory parlamentarne przerwały proces legislacyjny.

Niepewność regulacyjna odstrasza potencjalnych inwestorów od tej branży, przez co nie ma zainteresowania obligacjami emitowanymi przez instytucje pożyczkowe, nawet przy relatywnie wysokim oprocentowaniu, a także ogranicza dostęp do innych źródeł finansowania działalności pożyczkowej. Kolejnym czynnikiem w ramach obszaru regulacyjnego jest wyrok Trybunału Sprawiedliwości UE dotyczący zwrotu części prowizji przy przedterminowej spłacie kredytu konsumenckiego [Wyrok Trybunalu pierwsza izba z dnia 11 września 2019 r. w sprawie C-383/18], co oznaczało konieczność utworzenia rezerw na przyszłe roszczenia klientów w tym zakresie. Kwestią problematyczną stało się to, czy wszystkie koszty składające się na całkowity koszt kredytu konsumenckiego, a jeśli nie - to które $\mathrm{z}$ nich, podlegają wyrażonej w nim zasadzie proporcjonalnego obniżenia (redukcji) stosownie do okresu, o który został skrócony czas trwania umowy (okres kredytowania), w przypadku skorzystania przez konsumenta z przysługującego mu szczególnego uprawnienia do przedterminowej spłaty kredytu konsumenckiego [Rutkowska-Tomaszewska 2017]. Zgodnie ze wspólnym stanowiskiem Prezesa UOKiK i Rzecznika Finansowego z maja 2016 r., odsetki, opłaty i prowizje związane z kredytem konsumenckim powinny podlegać rozliczeniu [Stanowisko Rzecznika Finansowego i Prezesa Urzędu Ochrony Konkurencji $i$ Konsumentów $w$ sprawie interpretacji art. 49 ustawy o kredycie konsumenckim z dnia 16 maja 2016 r.]. Natomiast banki i instytucje pożyczkowe stały na stanowisku, że redukcji powinny ulegać tylko te koszty, które są związane z okresem kredytowania, a więc odsetki, natomiast opłaty i prowizje jako nie powiązane $\mathrm{z}$ okresem kredytowania nie powinny być proporcjonalnie rozliczane. Orzeczenie TSUE C-383/18 ucina ten spór na korzyść konsumentów, ponieważ zgodnie z tym orzeczeniem nie tylko odsetki, ale również opłaty i prowizje podlegają proporcjonalnemu rozliczeniu na podstawie okresu korzystania w kredytu konsumenckiego w porównaniu z całym okresem kredytowania [Wachnicka 2019]. Stanowisko takie zaprezentował również Prezes UOKiK w marcu 2020 r. [Stanowisko Prezesa UOKiK ws. interpretacji art. 49 ustawy o kredycie konsumenckim w kontekście wyroku TSUE z dnia 11 września 2019 r. ws. C-383/18 (Lexitor) z dnia 2 marca 2020 r.].

To i wiele innych czynników wpływa na restrukturyzację rynku, w tym opracowanie polityki, która ma na celu wdrożenie zasad odpowiedzialnego pożyczania (CSR), tak by klienci korzystający z nowych produktów pożyczkowych czuli się przede wszystkim bezpieczni. Działalność w zakresie przestrzegania norm etycznych, zasad społecznie odpowiedzialnego pożyczania, z czasem podniosą zaufanie społeczne do instytucji pożyczkowych [Paleczna 2018; Rutkowska-Tomaszewska i Paleczna 2018]. 


\section{PODSUMOWANIE}

Rynek pożyczek pozabankowych na przełomie 2019 i 2020 r. stanął przed wyzwaniem przezwyciężenia recesji spowodowanej czynnikami ekonomicznymi i regulacyjnymi. Podmioty działające na tym rynku nie cieszą się dużym zaufaniem i reputacją, ze względu na dużą skalę nieprawidłowości i nadużyć instytucji pożyczkowych ${ }^{5}$ i społeczny przekaz, że stosują lichwę wobec swoich klientów i działają nieetycznie. Rok 2021 będzie kluczowy dla branży pożyczkowej, biorąc pod uwagę projektowane regulacje oraz zapowiedzianą przez banki ofensywę na rynku kredytu gotówkowego o niższych kwotach. Ograniczenie skali legalnie działających instytucji pożyczkowych, stosujących obowiązujące przepisy prawa, w tym prawa konsumenckiego, może oznaczać przesunięcie części ich dotychczasowych klientów do pożyczkowej szarej strefy (podziemia kredytowego) oraz wzmocnienia pozycji lombardów, które poza lichwiarskim oprocentowaniem pożyczek prowadzą do zubożenia gospodarstw domowych $\mathrm{z}$ ich wyposażenia w dobra trwałego użytku - sprzęt AGD-RTV, telefony, komputery, narzędzia specjalistyczne. Skutek dalszego zaostrzania regulacji antylichwiarskich może być zatem odwrotny od zamierzonego celu. Ponadto sama branża pożyczkowa powinna eliminować podmioty stosujące nieuczciwe praktyki wobec konsumentów oraz w większym niż dotychczas stopniu położyć nacisk na kodyfikację norm etycznych $i$ ich stosowanie w praktyce przez instytucje pożyczkowe np.: poprzez wprowadzenie audytu etycznego (audyt taki realizuje Związek Przedsiębiorstw Finansowych wobec zrzeszonych członków). Jak wynika bowiem z badań prowadzonych w Polsce, wśród instytucji pożyczkowych zrzeszonych w ZPF i PZIP, Kodeksy etyczne nie są popularnym narzędziem kształtowania zachowań etycznych $\mathrm{w}$ badanych organizacjach, a poziom ogólności prezentowanych treści $\mathrm{w}$ nieznacznym stopniu przyczynia się do faktycznego kształtowania zachowań etycznych pracowników [Jaworska i Michniak-Szladerba 2019].

\section{BIBLIOGRAFIA}

Ancyparowicz G., Rutkowska I., 2014, Consumer finance w Polsce, „Zeszyty Naukowe Uniwersytetu Szczecińskiego: Finanse, Rynki Finansowe, Ubezpieczenia”, nr 67.

Barczuk K., 2011, Analiza rozwoju rynku consumer finance w Polsce, ,Prace Naukowe Uniwersytetu Ekonomicznego we Wrocławiu", nr 171.

Bernat M., 2018, Analiza regulacji prawnych dotyczacych sektora parabankowego - firm pożyczkowych, [w:] I. Jakubowska-Branicka (red.), Rynek firm pożyczkowych w Polsce. Teoria i praktyka, PWE, Warszawa.

${ }^{5} \mathrm{O}$ przykładach nieprawidłowości na rynku pozabankowego kredytu konsumenckiego można przeczytać w: m.in. Paleczna 2018 i Nieprawidtowości na rynku finansowym... 
Czechowska I.D., 2015, Niebankowe firmy pożyczkowe jako element shadow banking, „Przedsiębiorczość i Zarządzanie", t. 16, z. 8, cz. 3.

Domańska-Szaruga B., 2015, Rynek firm pożyczkowych w Polsce i propozycje jego uregulowania, [w:] J. Ostaszewski (red.), O nowy ład finansowy w Polsce - rekomendacje dla animatorów życia gospodarczego, Oficyna Wydawnicza SGH, Warszawa.

Domańska-Szaruga B., 2016, Bezpieczeństwo nieprofesjonalnych uczestników rynku pożyczek konsumenckich, [w:] K. Raczkowski, B. Wojciechowska-Filipek (red.), Wymiary zarządzania ryzykiem w obrocie gospodarczym, CeDeWu, Warszawa.

Dyrektywa Parlamentu Europejskiego i Rady 2014/17/UE z dnia 4 lutego 2014 r. w sprawie konsumenckich umów o kredyt związanych z nieruchomościami mieszkalnymi i zmieniająca dyrektywy 2008/48/WE i 2013/36/UE oraz rozporządzenie (UE) nr 1093/2010. Tekst mający znaczenie dla EOG (Dyrektywa MCD), Dz.U. UE L 60 z 28.2.2014, s. 34-85.

Gostomski E., Lepczyński B., 2009, Wpływ czynników społeczno-demograficznych na perspektywy rozwoju rynku consumer finance w Polsce, ,Transformacja i Rozwój”, nr 115.

Jaworska M., Michniak-Szladerba J., 2019, Kodeks etyczny jako narzędzie kształtowania zachowań etycznych $w$ pozabankowych podmiotach pożyczkowych, „Zeszyt Naukowy Wyższa Szkoła Zarządzania i Bankowości w Krakowie”, nr 52.

Kurzępa-Dedo K., Gemzik-Salwach A., 2018a, Ustawa antylichwiarska a zmiany na rynku instytucji pożyczkowych - wybrane zagadnienia (część 1), „Humanities and Social Sciences”, t. 23(XXIII), nr 25(2).

Kurzępa-Dedo K., Gemzik-Salwach A., 2018b, Ustawa antylichwiarska a zmiany na rynku instytucji pożyczkowych - wybrane zagadnienia (część 2), „Humanities and Social Sciences”, t. 23(XXIII), nr 25(3).

Nieprawidłowości na rynku finansowym a ochrona konsumenta. Raport Doradczego Komitetu Naukowego przy Rzeczniku Finansowym, Warszawa, wrzesień 2019 r., https://rf.gov.pl/pdf/DKN_Raport_nieprawidlowosci_wrzesien2019.pdf

Opolski K., Gemzik-Salwach A., Dwórznik M., Podleśna M., Wais K., Zapadka P., 2015, Sektor shadow banking $w$ Polsce, CeDeWu, Warszawa.

Paleczna M., 2018, Problem nieetycznych zachowań na rynku niebankowych kredytów konsumenckich, ,Studia Prawno-Ekonomiczne”, t. 109.

Pindel E., Martysz C., 2019, The background of regulating non-bank loan institutions in Poland, „Annales Universitatis Mariae Curie-Skłodowska”, Sectio H, vol. 53, no. 2.

Projekt ustawy o zmianie niektórych ustaw w celu przeciwdziałania lichwie z dnia 18 lutego $2019 \mathrm{r}$.

Rekomendacja T dotyczaca dobrych praktyk $w$ zakresie zarzadzania ryzykiem detalicznych ekspozycji kredytowych, 2010, Warszawa, luty.

Rudke M., GetBack psuje rynek firmowych obligacji, 2018, „Parkiet”, 11.05.

Rutkowska-Tomaszewska E., Paleczna M., 2018, Idea odpowiedzialnego kredytowania na rynku niebankowych kredytów konsumenckich w Polsce, „Internetowy Kwartalnik Antymonopolowy i Regulacyjny", nr 6(7).

Rutkowska-Tomaszewska E., 2017, Wynagrodzenie kredytodawcy zwiąane z procesem kredytowania a regulacja prawna obniżenia catkowitego kosztu kredytu konsumenckiego w przypadku jego przedterminowej spłaty jako przejaw ochrony interesów ekonomicznych konsumenta, [w:] Ochrona klienta na rynku ustug finansowych w świetle aktualnych problemów i regulacji prawnych, C.H. Beck, Warszawa.

Rynek firm pożyczkowych. Raport analityczny, 2016, Dom Maklerski NWAI, 22.01, https://www.nwai.pl/uploaded_files/15059825961000_rynek-firm-pozyczkowych-raportnwai.pdf [dostęp: 31.12.2019].

Sektor pożyczek pozabankowych - dwie strony rynku, 2019, Polski Związek Instytucji Pożyczkowych i Fundacja Rozwoju Rynku Finansowego, Warszawa, luty. 
Solarz M., 2007, Pośrednicy kredytowi i brokerzy ustug finansowych na rynku consumer finance w Polsce, ,Prace Naukowe Akademii Ekonomicznej we Wrocławiu”, nr 1186.

Stanowisko Prezesa UOKiK ws. interpretacji art. 49 ustawy o kredycie konsumenckim $w$ kontekście wyroku TSUE z dnia 11 września 2019 r. ws. C-383/18 (Lexitor) z dnia 2 marca 2020 r.

Stanowisko Rzecznika Finansowego i Prezesa Urzędu Ochrony Konkurencji i Konsumentów w sprawie interpretacji art. 49 ustawy o kredycie konsumenckim z dnia 16 maja $2016 \mathrm{r}$.

Ustawa z dnia 12 maja 2011 r. o kredycie konsumenckim, Dz.U. 2019, poz. 1083.

Ustawa z dnia 23 marca 2017 r. o kredycie hipotecznym oraz o nadzorze nad pośrednikami kredytu hipotecznego i agentami, Dz.U. 2017, poz. 819 ze zm.

Ustawa $\mathrm{z}$ dnia 5 sierpnia 2015 r. o zmianie ustawy o nadzorze nad rynkiem finansowym i niektórych innych ustaw, Dz.U. 2015, poz. 1357.

Ustawa z dnia 29 sierpnia 1997 r. - Prawo bankowe, Dz.U. 2019, poz. 2357 ze zm.

Wachnicka A., 2019, Redukcja kosztów w razie przedterminowej spłaty kredytu konsumenckiego w świetle orzeczenia TSUE C-383/18, „Internetowy Kwartalnik Antymonopolowy i Regulacyjny", nr 8.

Waliszewski K., 2010, Pośrednictwo kredytowe w Polsce, CeDeWu, Warszawa.

Waliszewski K., 2016, Rynek pozabankowych pożyczek konsumenckich w Polsce, CeDeWu, Warszawa.

Waliszewski K., 2017, Charakterystyka klientów instytucji pożyczkowych oraz poziom ich zadtużenia, [w:] A. Gemzik-Salwach (red.), Klienci instytucji pożyczkowych i ich ochrona, CeDeWu, Warszawa.

Wyrok Trybunału pierwsza izba z dnia 11 września 2019 r. w sprawie C-383/18.

[www1] www.knf.gov.pl/podmioty/Rejestry_i_Ewidencje/rejestr_instytucji_pozyczkowych [dostęp 15.03.2020].

\title{
DETERMINANTS OF RECESSION ON THE NON-BANK LOANS MARKET IN POLAND
}

\begin{abstract}
The tightening of banking regulations in the field of retail lending (recommendations of the Polish Financial Supervision Authority) led to a dynamic growth in the non-bank loans sector in Poland. In addition to the traditional (off-line) segment of loans granted at home and in stationary outlets - own and partner ones, e.g. through financial intermediaries in connection with the development of modern technologies in consumer finance (fin-tech), the remotely granted loans segment has been dynamically developed (on-line, digital lending, Lend-tech). During the dynamic growth of the loan sector, a number of prudential and loan consumer protection regulations entered into force, and the largest loan institutions were covered by the so-called bank tax. However, loan market statistics for 2019 show that from month to month the sales dynamics of non-bank loans fell to reach negative values at the end of the year, which in practice means a state of recession on this market. The purpose of the article is to identify the determinants of the recession of the non-bank loans market observed in 2019. The article uses literature on the subject, which consists of legal acts, scientific articles, reports and statistical data.
\end{abstract}

Keywords: non-bank loans, consumer loans, consumer finance market, anti-usury regulations. 